\title{
Economy of education: National and global aspects
}

\author{
Oksana Ishchenko-Padukova \\ Southern Federal University, \\ Rostov-on-Don, Russian Federation \\ oaishenko-padukova@sfedu.ru
}

Elena Kazachanskaya

Southern Federal University,

Rostov-on-Don, Russian Federation

elk.13@yandex.ru

Irina Movchan

Southern Federal University,

Rostov-on-Don, Russian Federation

ivmovchan@sfedu.ru

\section{Lukasz Nawrot}

Poznan University of Economics and Business,

Poznań, Poland,

l.nawrot@ue.poznan.pl

Abstract. Our paper focuses on the national economy of education. We assume that under the current conditions of the globalized world, the economy of education reveals its two-fold nature: on the one hand, it represents an element of the national economic system, and on the other, it is also a structural component of the global education system. Therefore, national economy of education is shaped up by both internal and external factors represented by national and international influences. We analyze here the functional composition and the methods of legal regulation of the economy of education under the conditions and provisions of the global geopolitical transformations. In addition, we use the empirical model of returns to education for showing the factors that impact the employability of young graduates at the labor market. Our results confirm the importance of education for achieving higher levels of income, both nationally and internationally. Finally, we come to the conclusion that its target function consists of the global promotion of national education and consolidation of national competitive position within the world education space.

Received:

April, 2017

1st Revision: September, 2017

Accepted: November, 2017

DOI:

10.14254/2071 $8330.2017 / 10-4 / 19$ 
Keywords: economy of education, education standards, globalization, transformation.

JEL Classification: I12, I24, R51

\section{INTRODUCTION}

The relevance of the problem we have selected for our research is preconditioned by the quality changes occurring today in the economy of education and its legal regulation, both within national boundaries and at the world level, under the influence of the current trends of globalization and accelerated information exchange. Such transformations predetermine the necessity of an integrated study of functional composition of the economy of education and development of the potentially efficient directions for improving the economic and legal mechanisms for its regulation. This research is an attempt to present the economy of education within the coordinates of its two-sector composition. The novelty of the research consists in a fundamentally new methodological approach to the analysis of functional composition of the economy of education. The methodology of the analysis stems from the analytical model of mixed economy (Mamedov, 1997) that allows expanding the toolkit range applied to studying the economy of education. The logic of the research is preconditioned by the consistency in current development trends of the economy of education, its functional composition and the mechanisms of its legal regulation.

\section{ECONOMY OF EDUCATION AND DEVELOPMENT TRENDS}

Nowadays, the world economy experiences quality change caused by the objective trends of geopolitical transformation and the expanding globalization process, which to a significant extent determines both the contemporary landscape of the world order and the national economic systems (Balitskiy et al., 2014; Čajka et al., 2014; Strielkowski \& Č́aelková, 2015). Under these conditions, an increasingly more aggregate mechanism of cross-border interactions is formed between the spheres of national economies, regulating institutions (Nawrot, 2013), and individual markets, pushing the competition beyond the national boundaries and aggravating the problems of stability for national economic subsystems (Kasperowicz, 2014). Very often, mass media, Internet and social networks also have a say in this (De Beer et al., 2015).

The processes touch on the national educational systems more and more (especially ones of the sphere of higher education). In conditions of global transformations, they become a structural element of the world economy of education, the rise of which is objectively conditioned by the trends of integration, cross-border mobility of the human capital, and the development of information and communication technologies (Janda et al., 2013; Zlyvko et al., 2014). Marginson et al. (2010) put this out as follows: "unlike other sectors, the sphere of higher education has always been more open within the international context, as knowledge cannot be limited by legally set boundaries".

Even now, the economy of education is not viable and competitive if it is confined within the territorial boundaries of a national economic complex and the subject of such an "autarchic" model of education cannot claim the leadership in the global layout of the international relationships. In the future, the globalization trends for the economy of education are only to enhance, which demands from the national educational systems a radical restructuring of the internal organization and regulation mechanisms 
and bringing them up to the global transformation challenges. The main manifestations of globalization in the economy of education are the following:

- shaping of the international market of education;

- cross-border education being intensified;

- IT penetration into education;

- merging and integration of national educational systems;

- standardization of educational systems based on cultural values unification.

Two current objective trends which formed in the economy of education under the action of the global geopolitical transformation processes should be outlined specifically.

First, processes of technological convergence between national systems of education can be seen that imply unification of programs and training levels, recalculation of academic hours into credit units, introduction of equivalence mechanisms for accreditation processes and so on.

Secondly, the trends of growing competitiveness of the national systems of education enhance at the expense of intensifying the cross-border forms of rendering the educational services (via implementation of franchising mechanisms or forming the branch networks), the international, program and institutional mobility of human resources (Vincent-Lancrin, 2010; Jankelová et al., 2017; Frankowska et al., 2015) and the intercultural educational exchange.

Hence the developed national educational systems act as the world leaders, attracting the students from other countries and thereby reducing the competitive potential of less developed closed local systems of education.

In the view of the mentioned trends, it is formation and implementation of such directions of the national economic policy in the sphere of education as to further its entering the global educational space and strengthening the competitive positions of individual elements and subjects of the educational environment that act as objective requirements for the national education economy.

High-quality education is a capital ensuring the development of any state. As both the society and the state need highly educated citizens, professional specialists knowing foreign languages, the state provides assistance in creating the required standards that ensure the quality of education and are up to the relevant objectives and tasks of education (Strielkowski et al., 2016). The specific nature of quality education standards - their sources, content, and extent of compulsoriness - is associated with the structure of quality assurance mechanisms. Practice shows the introduction of standards and adherence to them creates a competitive advantage in the educational services market.

Nevertheless, as Shepeleva (2013a) points out: "the quality of education cannot be viewed in isolation from the ideas about objectives and tasks... of education. It is on what objectives and tasks are set for the educational institutions that the requirements for the quality of education ultimately depend and so do the ways by which it is suggested to achieve that" (Shepeleva, 2013a).

Thus, depending on the ideas about the objectives and tasks of education, both the content of study programs and the teaching methods will change. So, for instance, if the task of education is the most complete training for practice, then it is the practical component that will have to be increased in the educational program. Using the example, one can see how the views on the objectives and tasks of education may influence the formation of quality standards which can be imposed not only by the state but also by special authorities or professional association. Meanwhile, the standards may be both general and detailed and have both the compulsory and recommended character. 


\section{FUNCTIONAL COMPOSITION OF THE ECONOMY OF EDUCATION}

The economy of education can be viewed as an integral system only from the standpoint of the "twosector" approach - by singling out in its composition the market and the non-market sectors, each having quite particular structural attributes and various regulation mechanisms.

The conceptual grounds for the two-sector functional composition of the economy of education are provided by the "model of mixed economy" (Mamedov, 2001), which presents the composition of the modern economy as the interaction of the market and non-market sectors of production. Based on the classical market concept, the model of mixed economy has a universal methodological character and acts as an analytical tool for researching the composition of complex subsystems and the sphere of national economy. "In the generalized model of composition of the modern economy as an economic system of a mixed (two-sector) type, it is only the inevitability and necessity of combining the two polar, alternative, completely opposite forms of social production organization - the "market" one and "non-market" one that is meant by the "mixed character" of today's economy" (Mamedov, 2001).

The two-sector model of mixed economy expands the methodological boundaries of studying the economy of education. According to the model suggested by Mamedov (2001), the functional composition of the economy of education has the following appearance: within the coordinates of the two-sector model, functional potential of the economy of education is fulfilled by the interaction of the market and non-market sectors within which both the direct process of education (as a form of educational services provision) and the mechanism of its regulation are ensured.

In research literature, the market of education is understood as "contractual relationships which are entered by consumers and producers of educational services for the purpose of buying or selling an educational service" (Romanova et al., 2012). When applying the methodological toolkit of the two-sector model of mixed economy, it can be made more precise that the market sector of the economy of education (OKED) is the space of interaction of an "efficient customer" and "efficient seller" (Mamedov, 2001) of the educational service, while the non-market sector, a "quasi-market (DEMC), emerges as a result of "staged" (discrete) growth in that share of the unable to pay part of the need of an artificially ("by the state") organized market" (Mamedov, 2001). Even though "education is a public good in its social and economic nature and alongside with science, culture and healthcare belongs to the mixed sector of the national economy" (Starovoytova, 2009), within the methodological coordinates of the two-sector model of mixed economy, an educational service acts as an exclusively private good paid for by an individual independently - in the market sector of the economy. Meanwhile, in the non-market sector - the same educational service gains the character of a private good paid for at the public expense, because "the function of the non-market sector of the economy consists in production of goods in the situation of the "supply price" exceeding the "demand price" obviously" (Mamedov, 2001).

\section{MARKET SECTOR OF THE ECONOMY OF EDUCATION}

The market sector of the national economy of education is represented by the supply subjects producers of educational services, the demand subjects - individuals, companies, organizations, control bodies, as well as the intermediaries - social institutions and structures helping the promotion of educational services at the market (Romanova et al., 2012) and interacting about buying and selling of educational services. Under globalization, alongside with the national producers of educational services, it is the transnational educational corporations, non-governmental organizations, trust educational and charity foundations are the actors of the economy of education. Their activity expands the parameters of the education economy market sector. 
Regardless from the institutional status, the organizational and legal form of an educational institution, within the coordinates of the two-sector model of mixed economy, the sizes of the market sector (OKED) of the economy of education are determined by the volume of the effective demand for the educational services and by the extent of elasticity of the educational services demand and supply.

Mamedov points out that "in the range of theoretically possible combinations of various elasticity of demand and supply curves, there are two situations that act as alternative ones: the combination of low elasticity demand with high elasticity supply and the combination of high elasticity demand with the low elasticity supply" (Mamedov, 2001). Proceeding from this, two alternative models of the economy of education can be described: i) the education economy model formed by the high elasticity demand. Here, the "unsatisfied by the market part of need is increased fairly, which means narrowing down of the market sector of the economy of education and growth of the public spending on organizing the system of education; ii) the education economy model formed by the low elasticity demand. Mamedov (2001) points out: "given the lower elasticity of demand, the role of the market increases while reducing the society's burden of spending for satisfaction of the part of need which is not covered by the demand". Figure 1 below illustrates this process.
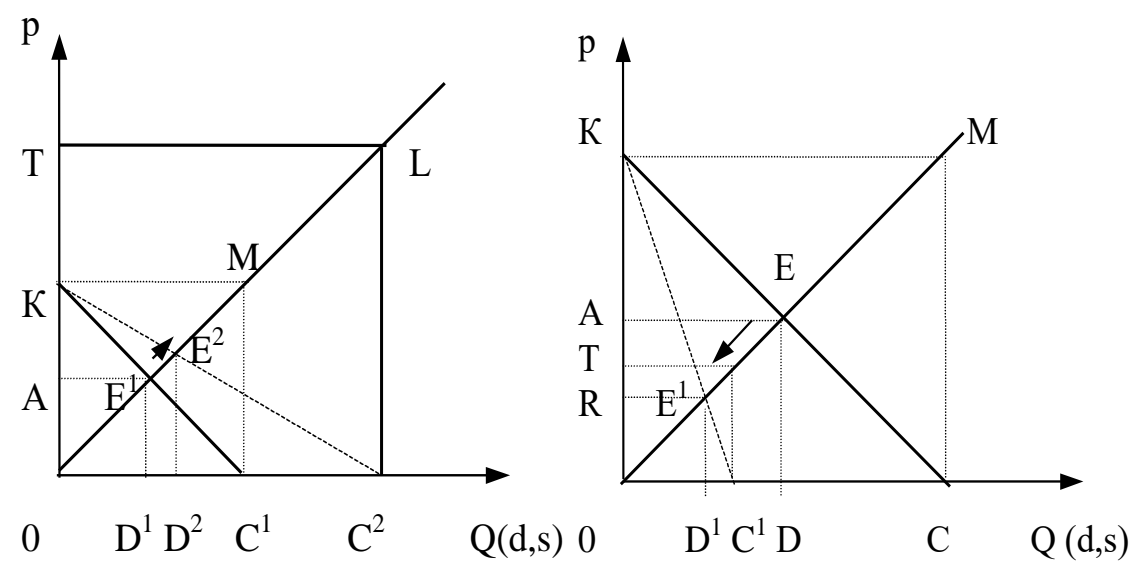

Figure 1. Dynamics of economic parameters under the high (left) and low (right) elasticity demand Source: Mamedov (2001)

The low elasticity of the demand for educational services is characteristic for a highly developed and efficiently organized economy of education in which even a considerable rise of prices for educational services will not result in both the internal and the external demand decrease. This is ensured by a high reputation of the national producers of educational services, because "the high-quality systems of higher education having broad connections at the international level promote the global development owing to the exchange of students, researchers, projects and ideas over the national boundaries" (Ranking of national higher education systems, 2016).

Within the context, the state gains an important function - alongside with regulation and financing of the national education - it has to take measures on stimulating the internal and external private effective demand for educational services.

\section{NON-MARKET SECTOR OF THE ECONOMY OF EDUCATION}

The non-market sector of the economy of education within the national boundaries is determined by two main functions of the state: financing the educational institutions at the expense of budget sources and determining the principles, methods and mechanisms of organization and regulation of the national 
education economy. Within the context of the functional model of two-sector composition of the economy of education (DEMC), the non-market sectors undertake financing of the unable to be paid for part of need which is socially important and up to the objectives and requirements of the national economic development in the strategic outlook.

In the global space, the non-market sector of the economy of education is represented by the regulating institutions of the national and supranational levels: national ministries of education conducting the economic policy in the sphere of educational services export and the international regulating organizations (WTO, The World Bank, European Union, OECD) (Eremina et al., 2013).

The efficiency of national economy of education and its globally competitive potential is determined by the regulating role of the state both in the organizational and in the financial aspects. Although there are essential distinctions in various models of the national education economy regulation, the state plays the key part in its financial support and regulation. S. Marginson and M. van der Wende note that "the extent of the higher education institutions' isolation from the state should not be exaggerated. Most universities remain nationally inbuilt and depending on the governmental regulation and resource support. The national state does not disappear: it stays overarching in the economic activity" (Marginson et al., 2010).

Under today's conditions of globalization, this inevitably keeps causing questions associated with the efficiency of the non-market (state) sector of the economy of education both in the organizational and managerial and in the financial aspects, as well as with the implementation of the national economic policy in the sphere of education. The contemporary studies of the economic policy in education, as a rule, proceed in one of the three forms:

- the development of analytical models using which the process of education can be explored as a theoretical structure and as a set of promising practices;

- the analysis of a number of economic, social and political questions predetermining the formation of this or that model of economic policy in the sphere of education;

- critical studies which currently prevail in the economic science relating the forms and methods of organization of the economic policy in education.

These approaches being rather fragmented frequently fail to ensure the completeness of analysis and the constructiveness of practical type conclusions. The modern economy of education should be viewed within the coordinates of its two-sector composition in an integrated way, with global trends taken into account. Proceeding from this, education economy regulation under globalization has to have an accorded basis at various levels of national and supra-national interaction and has to rely on the concepts of human capital, civil responsibility and social justice, in order to provide for the analysis of prevailing discourses and advanced models which formed an efficient education policy in the developed countries of the world. However, regulation of the economy of education is not a linear process, because for each national system, efficiency factors can vary depending on the mentality, national traditions, specific character of the internal market of educational services, and the social, economic and technological development level.

Moreover, the process of developing the economic policy in education is a dialectic one in which the institutional interests of all its subjects have to be taken into account. Marginson et al. single out "four separate yet mutually penetrating spaces in which the governments and higher education institutions, both individually and in cooperation, elaborate the strategies and policy in the area of education. These are the intergovernmental negotiations, the global connections of the institutions, conditions of national educational systems created by the governments, and the universities' local programs of actions" (Marginson et al., 2010).

In the broad context, economic policy in education is a subject of interdisciplinary studies as it is inseparably associated with political and managerial decision making, social factors, national and mental 
particularities and value reference points of the population, as well as the trends of global education and the international labor market (Strielkowski et al., 2016).

In the economy of education, the political context has quite an important influence on the forming of the institutional environment. Therefore, when forming an efficient economic policy in the sphere of education, the key objective consists in studying the interrelation between the development of the policy at the institutional level with the effect of national and local conditions borne in mind.

The key problem in forming the economic policy in education is studying the interrelation between the organizational and the operative level of its implementation, i.e. the questions how much the decisions made at the political level are up to the economic needs of this sphere.

\section{LEGAL REGULATION OF THE ECONOMY OF EDUCATION}

The analysis of education economy in the coordinates of its two-sector functional composition allows describing the functions of legal regulation by the state within the boundaries of the market and non-market sectors in more detail. The national legal regimes in education economy regulation are formed according to the objectives and priorities declared in educational policy of this or that country.

In any democratic state, human rights are the top value, with the right for education occupying a special place among them. Being a process of development and self-development of a personality, education is an indispensable condition for preserving and developing the material and spiritual culture. Socially important experience of the humanity which is embodied in knowledge, abilities, creative activity, emotional and value-based attitude to the world is learned by means of education. As it is on the quality of education of the citizens that the development of the society and the state as a whole depends, education has not only the social, economic but also the legal aspect (Dubrova, 2015).

In particular, within the national education economy, the state determines the "rules of the game" for organizations performing the educational activity and sets up the "framework terms" of the educational process. The efficiency of the legal regulation regime for the economy of education is determined by the optimum proportion of its market and non-market sectors. Currently, the question is still debatable whether the state should play the part of regulator towards the educational sphere: determine the "rules of the game" for educational institutions and teachers, to regulate the work of educational institutions in detail, setting the requirements for the content of study programs, teaching methods, qualification of teachers, as well as control the conformity of educational institutions to these requirements" (Shepeleva, 2013).

An indispensable requirement for organization of legal regime of the national education economy is its not contradicting the system of international legal norms.

For the first time ever, the right for education was consolidated by the Universal declaration of human rights in 1948. So, as Article 26 reads, "Education shall be directed to the full development of the human personality and to the strengthening of respect for human rights and fundamental freedoms. It shall promote understanding, tolerance and friendship among all nations, racial or religious groups, and shall further the activities of the United Nations for the maintenance of peace."

Further on, the provision on education was reflected in the International covenant of the economic, social and cultural rights of 1966. Based on the Universal declaration, Article 13 of the Covenant stipulates that "Education shall be directed to the full development of the human personality and the sense of its dignity, and shall strengthen the respect for human rights and fundamental freedoms. They further agree that education shall enable all persons to participate effectively in a free society, promote understanding, tolerance and friendship among all nations and all racial, ethnic or religious groups, and further the activities of the United Nations for the maintenance of peace". 
While the International documents of the mid-20th century actually consolidate each person's right for education, the subsequent ones - e.g. the European Union Charter of fundamental rights of 2000 (Article 14 speaks about the "freedom to to found educational establishments with due respect for democratic principles ... in accordance with the national laws governing the exercise of such freedom and right") - not only confirm such right and prohibits any discrimination in fulfillment of the right for education (the ban was detailed in Recommendation against discrimination in education of 1960 which by discrimination meant "any distinction, exclusion, limitation or preference" in this or that attribute and expressly stating a prohibition of such actions (UN, 1960)) but also determine certain directions for it to be developed in. So, for instance, they speak about ensuring free of charge education, introducing a system of scholarships, improving the teachers' material conditions etc. Later the Universal copyright convention of 1971, Recommendation on the development of adult education of 1976 saw the light as well as other various conventions on acknowledging the study courses, diplomas and other qualification documents within the system of higher education (UN, 1971).

With regard to this, the document adopted by UNESCO in Paris in 1998 and called the "World declaration on higher education for the twenty-first century: vision and action" is undoubtedly of interest. In it, tasks the education faces are worded and its main functions are determined, among which there are scientific research, bringing the objectives of education in line with the society's needs, the necessity of adherence to the professional ethic standards, attention to be paid to the needs of the labor market, science and economy. The Declaration specifically stipulates that entrepreneurial skills have to be formed in learners, because it is only in this case that the graduates will be able to act not only as job-seekers but also as job-creators.

By acknowledging the right for education as one of the main and inherent constitutional rights of citizens, any democratic state establishes the priority of education in the state policy and consolidates this right in the state's principal law which allows identifying the main principles of regulation of education (Yagofarov, 2004). Among them, the following can be listed: creation of conditions for the development of education, taking into account the needs of the society and the state, the development of the economy and the labor market while forming the policy in the sphere of education, conformity to the genera world criteria of quality etc. - for it is the high education level that enables both the creative and intellectual capacity of an individual and the innovation and technological potential of the national economy to be fulfilled. What unites the direction of development of education in any state is the conformity of education policy to the existing social relationships and to the mechanism of legal regulation ensuring the required quality level of education.

Relying on the principles and norms consolidated by the UN Charter, the Universal declaration of human rights and by other international documents regulating the relationships in the sphere of education, the constitutions of democratic states consolidate the state and legal guarantees of the right for education. Among them, there is quality assurance of education, general availability, support for the gifted ones and assistance to those in need. Alongside with the principal law consolidating the right for education, the legal aspects of education are stipulated in certain laws developing the basic clauses on education, standards, provisions, and are ensured via creation of various agencies for quality assurance in education. As a rule, constitutions being the principal law of a state highlight education as the paramount task of the state, because the objective of education is the professional upbringing and forming of free and responsible citizens.

In the today's time of development of the right for education, the legal support of education is also focused on looking for the grounds of interaction for the state, professional community and the academic staff in determining the content of study programs in order to achieve the required education quality level. 


\section{EMPIRICAL MODEL}

It is true that good and prestigious education is merely the springboard for the promising career and returns to the human capital. Therefore, it is very important in the debate on the returns of investments to education. Both national and global economy of education should be first of all concerned with the issue of whether it provides its students with the necessary skills and knowledge for making the decent living. In our case, we would like to look into the relationship between the years of education (schooling) and the expected (and gained) income after getting a paid job.

In the empirical part of this paper which serves as the illustration to our previous discussion, we compare the returns to education and the correlation of the level and the quality of education with the performance on the labour market. We employ the micro-level data for the year of 2015 (due to the data completeness and availability) collected in Germany by the Federal Statistical Office (2017). We compare the returns to education for the three groups based on their nationality: the Germans, immigrants from the third countries, and the EU citizens. It is expected that the conditions of the Germans on the German labour market should be better than the conditions of the other groups. Moreover, one can also expect that the return to education will be higher for the immigrants from the EU Member States because of the more similar education system then in the other states.

Our dependent variable is represented by the average monthly income in 2015. This variable was constructed by dividing the average income for the whole year by the number of months while in the job during the year 2009. We used gross income because it is not influenced by the taxation which can differ for various income groups.

Furthermore, we restricted our sample of population on people born after the year 1944 which represents the pivotal point for measuring the working population in Germany. This is done due to the fact that including the whole population would influence the correctness of the results.

Our dependent variables for the regression were selected using the method popularized by Mincer (1974). Using the Mincer's approach, we arrived at the formal model that can be expressed by the equation assuming the following form:

$$
\ln Y_{S}=\ln Y_{0}+\beta_{1} t+\beta_{2} t^{2}+r s
$$

where:

$\mathrm{Y}_{\mathrm{s},-}$ income in the objected year,

$\mathrm{Y}_{0}$ - initial income,

$\mathrm{s}$ - years of schooling,

$r$ - interest rate,

$\mathrm{t}$ - number of years working.

First of all, we used as independent variables the number of years at school, and to measure the experiences we took the age and age squared. Unfortunately, the age and age squared are too much correlated, so we decided to let one of them out. We let the age in the equation, because based on the coefficient of determination it seemed to explain the model better.

Further, we used other independent variables step by step. Specifically, we used the Ordinary Least Squared (OLS) model approach. We used this model for the whole population to find the right variables and then we applied it to the single groups. The model seems to have the highest quality for variables: schooling, age, experience in full time job, experience with unemployment, average number of hours worked per week and then the dummy variables for gender and the marital status. 
The variables which didn't explained the model so good were following: length of working in parttime job, information if the person was born in Germany. For the whole population it was not important whether the person uses in her or his daily life the German language or other languages. However, it is important to mention that the model does not comply the condition of homoskedasticity and normality of residuals. The results of our estimations are shown in Table 1.

Table 1

Results of the empirical models for returns to education

\begin{tabular}{|l|c|c|c|}
\hline \multicolumn{1}{|c|}{ Variables } & Germans & $\mathbf{3}^{\text {rd }}$ country nationals & EU nationals \\
\hline Constant & $-20.371^{* * *}$ & 3.221 & -2.131 \\
\hline Years of schooling & $5.327^{* * *}$ & $6.027^{* * *}$ & $6.631^{* * *}$ \\
\hline Age & $-0.762^{* * *}$ & -1.053 & -1.043 \\
\hline Experience - full time job & $1.0222^{* * *}$ & $2.251^{* * *}$ & $1.433^{* * *}$ \\
\hline Experience-unemployment & $-3.172^{* * *}$ & $-2.272^{*}$ & $-4.024^{*}$ \\
\hline Average number of hours worked per week & $0.133^{* * *}$ & $0.142^{* * *}$ & $0.177^{* * *}$ \\
\hline Male & $21.222^{* * *}$ & 20.517 & $28.112^{* *}$ \\
\hline Married (living with a partner) & $17.341 * * *$ & -17.214 & -24.265 \\
\hline R-squared & 0.153 & 0.152 & 0.194 \\
\hline Number of observations & 15644 & 853 & 655 \\
\hline
\end{tabular}

Note: $* 15 \%$ level of significance, $* * 10 \%$ level of significance, ${ }^{* * *} 5 \%$ level of significance Source: Own results

The most important finding in our model is the difference in the returns to education among the three groups in question. Our results reveal that an additional year of schooling increases the wage of Germans by $5 \%$. Furthermore, it appears that education has even more significant impact on the wage of the immigrants. In the case of $3^{\text {rd }}$ country nationals (non-EU citizens), an additional year of education increases the wage by $7 \%$, while the same result for the EU citizens appears to be $7.5 \%$. One can guess that the higher importance of education for immigrants in the example of Germany in question could be connected to the knowledge of foreign languages. One can conclude that the more educated the people are, the higher is their ability and their command of foreign language(s). And it is unquestionable that knowing more foreign languages provides wider employment opportunities.

Another interesting and important result obtained from our empirical model is the impact of the working experience. We attempted use this variable as well in the squared form but similarly to the case of the age variable, the experience (the length) of full time job came through as correlated with the square of this variable, so the single version was used. Our results confirm that the additional year spent in employment increases the salary from $2 \%$ to $3 \%$. The last variable that came through as significant for the all three group was the average amount of hours worked. The other variables in our model did not come through as significant for the immigrant group, so it was not possible (and meaningful) to compare them. This result was most probably caused by the insufficient number of observation in the groups in question.

All in all, our results confirm that the internationalization of education might bring great benefits to the national and international economy. Thence, it is very desirable to further deepen and support the internal and external factor leading to this process. 


\section{CONCLUSIONS AND IMPLICATIONS}

In the conditions of globalization, the national economy of education experiences the influence of the objective trends associated with expansion of the international education market, intensification of cross-border education, accelerated development of the information and communication sphere, and unification of the educational process organization principles. In these circumstances, new theoretical and methodological approaches and concepts are needed that allow exploring the entire range of the dynamic processes and system upgrades in the education economy sphere in an integrated manner.

The economy of education being an integrated system needs two sectors to be subdivided in its composition, the market one and non-market one, that have particular structural attributes and various mechanisms of economic and legal regulation, i.e. it can only be viewed from the standpoint of "twosector" approach. This approach expands the methodological boundaries of studying the economy of education in the theoretical aspect. In the applied aspect, it allows identifying the vector of efficient development of the national education economy and its legal regulation regime, with globalization trends borne in mind.

Studying the economy of education in the methodology of its two-sector functional composition predetermines the legal regulation regime of the state as the actor of educational process in the nonmarket sector and as the regulator of educational process in the market one. Although national legal regimes in education economy regulation are formed in line with the objectives and priorities declared in the area of educational policy by this or that country, the world education development trends have to be taken into account for enhancing the competitiveness and diversifying the educational products available. Thus, the efficiency of the legal regulation regime for the economy of education determines the optimum proportion of its market and non-market sectors.

\section{REFERENCES}

Balitskiy, S., Bilan, Y., \& Strielkowski, W. (2014). Energy security and economic growth in the European Union, Journal of Security \& Sustainability Issues, 4(2), 123-130. http://dx.doi.org/10.9770/jssi.2014.4.2(2)

Čajka, P., Jaroszewicz, M., \& Strielkowski, W. (2014). Migration Incentives and Flows between Belarus, Moldova, Ukraine and the European Union: a Forecasting Model. Economics and Sociology, 7(4), 11-25. http://dx.doi.org/10.14254/2071-789X.2014/7-4/1

De Beer, A., S., Láb, F., Strielkowski, W., \& Tejkalová, A., N. (2015), Business influence on media news processing: a comparison of journalists' perceptions in the Czech Republic and South Africa. Economics and Sociology, 8(1), 222-233. http://dx.doi.org/10.14254/2071- 789X.2015/8-1/17

Dubrova, A.N. (2015). Pravo na obrazovanie kak odno iz konstitutsionnykh prav cheloveka [Right for education as a constitutional right of the individual]. Molodoy ucheniy = Youbg scholar, 10, 12-22

Eremina, S.L., \& Yalovega, I.E. (2013). Mirovoy rynok obrazovatelnykh uslug: sostoyanie i struktura [The world market of educational services: condition and structure]. Proceedings of Tomsk Polytechnical University. Inzhiniring gheoresursov publishers, 322(6), 38-41.

European Union charter of fundamental rights of 2000. (2017). Retrieved from http://eulaw.ru/treaties/charter

Federal Statistical Office. (2017). German labor market statistics. Retrieved from https://www.destatis.de/EN/FactsFigures/NationalEconomyEnvironment/LabourMarket/Methods/Offici al LabourMarket.html

Frankowska, A., Głowacka-Toba, A., Rasińska, R., \& Prussak, E. (2015). Students entering the labour market, their hopes, expectations and opportunities in the context of sustainable economic development. Journal of International Studies, 8(3), 209-222. 
International covenant of the economic, social and cultural rights of 1966. (2017). Retrieved from http://www.un.org/ru/documents/decl conv/conventions/pactpol.shtml

Janda, K., Rausser, G., \& Strielkowski, W. (2013). Determinants of Profitability of Polish Rural Micro-Enterprises at the Time of EU Accession. Eastern European Countryside, 19, 177-217. https://doi.org/10.2478/eec-2013-0009

Jankelová, N., Jankurová, A., \& Masár, D. (2017), Effective management and self-government: current trends. C飞ech Journal of Social Sciences, Business and Economics, 6(2), 21-31. http://doi.org/10.24984/cjssbe.2017.6.2.3

Kasperowicz, R. (2014). Electricity consumption and economic growth: Evidence from Poland. Journal of International Studies, 7(1). doi: 10.14254/2071-8330.2014/7-1/4.

Mamedov, O.Yu. (1999). Ot modeli klassicheskogo rynka - ke modeli smeshannoy ekonomiki [From the classical market model - to the mixed economy model]. Rostov-on-Don: Feniks Publ.

Mamedov, O.Yu. (2001). Smeshannaya ekonomika. Dvukhsektornaya model [Mixed economy. Two-sector model]. Rostov-onDon: Feniks Publ.

Marginson, S., \& van der Wende, M. (2010). Noviy globalniy stranovoy i institutsionalniy landshaft [The new global landscape of nations and institutions]. Bulletin of international organizations, 3(29), 45-85.

Mincer, J. (1974). Schooling, experience, and earnings. New York: Columbia Press.

Nawrot, Ł. (2013). Renewable energy sources as a new research area in tourism. Poznań University of Economics Review, 4, 67-82.

Romanova, I.M., Shevchenko, O.M., Polupanova, V.A. (2012). Sushchnost, struktura i osobennosti rynka obrazovatelnykh uslug [The essence, structure and particularities of the educational services market], Marketing $v$ Rossii $i$ za rubezhom $=$ Marketing in Russia and abroad, 3. Retrieved from http://mavriz.ru/articles/2012/3/6350.html

Shepeleva, O. (2013). Problemy yuridicheskogo obrazovaniya na tekushchem etape reformy [The problems of legal education at the current stage of the reform]. Yuridicheskoe obrazovanie: poisk novykh standartov kachestva = Legal education: looking for new quality standards, 81-166.

Shepeleva, O. (2013a). Kak tseli yuridicheskogo obrazovaniya svyazany s ponimaniem ego kachestva [How the objectives of legal education are associated with understanding of its quality]. Yuridicheskoe obrazovanie: poisk novykh standartov kachestva = Legal education: looking for new quality standards, 167-177.

Starovoytova, T.A. (2009). Formirovanie i razvitie rynka obrazovatelnykh uslug v Rossii [Formation and development of the educational services market in Russia]. Digital scientific publication "Proceedings of NSUEM", Novosibirsk, 2.

Strielkowski, W., \& Čábelková, I. (2015). Religion, Culture, and Tax Evasion: Evidence from the Czech Republic. Religions, 6(2), 657-669. http://dx.doi.org/10.3390/rel6020657

Strielkowski, W., Kalyugina, S., Tumanyan, Yu. (2016). Labour Market Inclusion of International Protection Applicants and Beneficiaries. Economics \& Sociology, 9(2), 293-302. http://dx.doi.org/10.14254/2071789X.2016/9-2/20

UN. (1960). Recommendation against discrimination in education of 1960 . Retrieved from http://www.un.org/ru/documents/decl conv/conventions/educat

UN. (1976). Recommendation on the development of adult education of 1976 . Available: http://www.un.org/ru/events/literacy/doc.htm

Universal Copyright Convention of 1971. (1971). Retrieved from http://www.un.org/ru/documents/decl conv/conv1970.shtml

Universal Declaration of Human Rights of 1948. (1994). Universal Declaration of Human Rights. 45 $5^{\text {th }}$ anniversary years 1948-1993, Moscow. Retrieved from http://www.ohchr.org/EN/UDHR/Documents/UDHR Translations/rus.pdf. 
Universitas 21. (2016). Ranking of national higher education systems of 2016. Gumanitarnye tek.hnologhii $=$ Humanitarian technologies. Information and analytics portal. Retrieved from http://gtmarket.ru/news/2016/08/25/7298.

Vincent-Lancrin, S. (2010). Transgranichnoe vysshee obrazovanie: tendentsii i perspektivy razvitiya [Cross-border higher education: trends and prospects of development]. Bulletin of International Organizations, 3(29), 86-109.

World Declaration on Higher Education for the $21^{\text {st }}$ Century: Vision and Action (2000). Collection of documents on the international aspects of bigher education. Saint-Petersburg. Retrieved from http://docs.cntd.ru/document/901839539

Yagofarov, D.A. (2004). Pravovoe regulirovanie sistemy obrazovaniya. Uchebnoe posobie [Legal regulation of the system of education. A study guide]. Moscow: Moscow pedagogical state university.

Zlyvko, O., Lisin, E., Rogalev, N., \& Kurdiukova, G. (2014). Analysis of the concept of industrial technology platform development in Russia and in the EU. International Economics Letters, 3(4), 124-138. http://doi.org/10.24984/iel.2014.3.4.2 